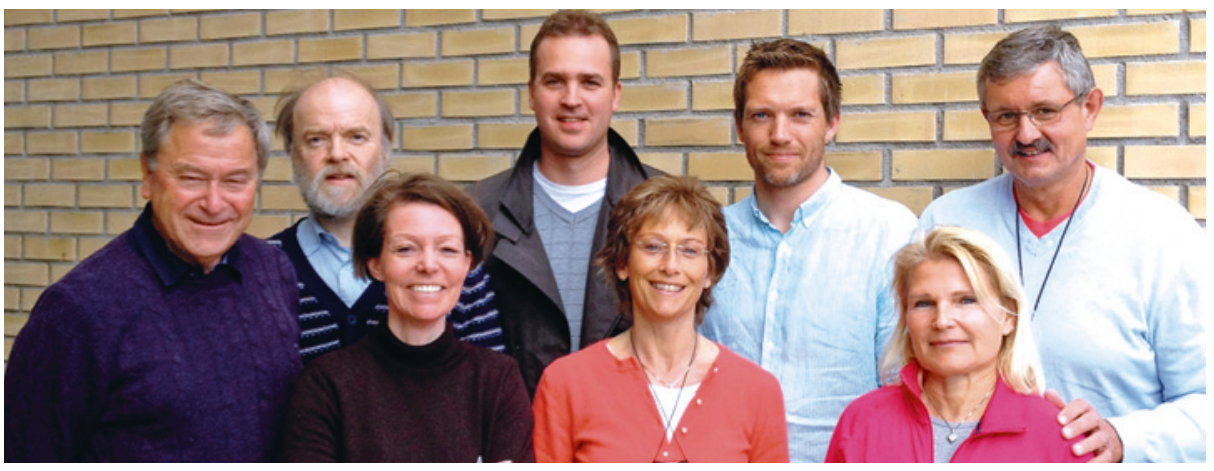

Fra venstre professor Kai-Håkon Carlsen, lege og lokalt ansvarlig Leif Bjarte Rolfsjord, forskningssykepleier Live Nordhagen, lege og lokalt ansvarlig Jon Olav Hunderi, professor og prosjektleder Karin C. Lødrup Carlsen, lege og førsteforfatter Håvard Ove Skjerven, lege Bente Kvenshagen og statistiker Petter Movinckel. Foto ORAACLE-gruppen

\title{
Ikke nødvendig med adrenalin ved akutt bronkiolitt
}

Inhalert racemisk adrenalin er ikke mer effektivt enn inhalert saltvann til behandling av barn med akutt bronkiolitt.

Akutt bronkiolitt er den hyppigste årsaken til akutt sykehusinnleggelse hos barn i Norge. Inhalasjoner med adrenalin har dokumentert symptomeffekt og har vært en del av standardbehandlingen for disse pasientene i flere tiår. Adrenalin anbefales også i internasjonale retningslinjer. Det har så langt manglet kunnskap om hvorvidt type inhalasjonsstrategi kan påvirke sykdomsforløpet.

Det er nylig gjennomført en randomisert, dobbeltblind multisenterstudie ved en rekke barneavdelinger i Helse Sør-Øst. Effekten av inhalert racemisk adrenlin ved akutt bronkiolitt ble sammenliknet med effekten av inhalert saltvann (1). Inhalasjoner etter behov versus inhalasjoner med faste intervaller ble også studert. Studien omfattet 404 barn under 12 måneder med moderat til alvorlig bronkiolitt. De ble randomisert i fire grupper med ulik medisin og ulik inhalasjonsstrategi.

Forfatterne fant ingen signifikant forskjell mellom saltvanns- og adrenalininhalasjoner i liggetid, behov for oksygentilskudd, bruk av ernæringssonde, ventilasjonsstøtte eller relativ klinisk bedring etter første inhalasjon. Liggetiden var signifikant kortere hos barn som fikk inhalasjoner etter behov $(47,6 \mathrm{t}$ $(95 \%$ KI 30,6-64,6 t)) fremfor med faste intervaller (61,3 t (95\% KI 45,4-77,2 t; $\mathrm{p}=0,01)$. «Etter behov»-strategien førte til mindre bruk av oksygentilskudd (38\% versus $49 \%, \mathrm{p}=0,04)$ og ventilasjonsstøtte $(4,0 \%$ versus $11 \% ; p=0,01)$ og færre inhalasjoner (12 versus $17 ; \mathrm{p}<0,001$ ).

- Vår konklusjon er at inhalert racemisk adrenalin ikke er mer effektivt enn inhalert saltvann hos barn som innlegges i sykehus med akutt bronkiolitt, sier Håvard Ove Skjerven, klinisk stipendiat og lege ved Barnemedisinsk avdeling, Oslo universitetssykehus, Ullevål. Han er førsteforfatter av artikkelen. - Inhalasjoner bør gis etter behov og ikke med faste intervaller. Resultatene har allerede ført til endrede behandlingsretningslinjer for akutt bronkiolitt i Norge og kan bidra til forenklet og forbedret behandling av disse pasientene også internasjonalt, sier Skjerven.

\section{ORAACLE-gruppen}

Bronchilitis ALL SE-Norway-studien er gjennomført i regi av forskningsgruppen ORAACLE (Oslo Research group of Asthma and Allergy in Children, the Lung and Environment) ved Oslo universitetssykehus og Universitetet i Oslo under ledelse av professorene Karin C. Lødrup Carlsen og Kai-Håkon Carlsen. ORAACLE-gruppen ble opprettet som ledd i Helse Sør-Østs forskningssatsing som et fagspesifikt kjernekompetansemiljø i et regionalt nettverk med nesten alle landets barneavdelinger. Studien er et resultat av dette samarbeidet.

Håvard Ove Skjerven har stått for løpende administrasjon av studien. Med unntak av ORAACLE-statistiker Petter Mowinckel var de øvrige 11 medforfatterne - Jon Olav Hunderi, Jon Lunde, Bente Kvenshagen og Marius Haavaldsen (alle Fredrikstad), Truls Vikin (Lillehammer), Leif Bjarte Rolfsjord (Elverum), Sabine Brügmann-Pieper (Drammen), Hanne Engen (Skien), Christian Siva og Charlotte Brun (begge Tønsberg) og Leif Eskedal (Kristiansand) - leger i kliniske stillinger ved de deltakende barneavdelingene. Deres innsats samt innsatsen fra opp mot 1000 andre involverte helsearbeidere var helt nødvendig for studiens gjennomføring.

\section{Hanne Støre Valeur}

hanne.store.valeur@legeforeningen.no Tidsskriftet

\section{Litteratur}

1. Skjerven HO, Hunderi JO, Brügmann-Pieper SK et al. Racemic adrenaline and inhalation strategies in acute bronchilitis. N Engl J Med 2013; 368: 2286-93.
Ordforklaringer

Akutt bronkiolitt: En obstruktiv luftveissykdom som særlig rammer barn inntil to år. Sykdommen forårsakes av en virusinfeksjon, oftest RS-virus eller metapneumovirus, som gir inflammasjon i slimhinnene i bronkiolene.

Inhalasjonsbehandling: Inhalasjon av legemidler for direkte administrasjon til luftveiene.

Racemisk adrenalin: Inhalasjonsmedisin som primært brukes i sykehus og på legevakt. Medisinen virker slimhinneavsvellende og noe relakserende på musklene rundt luftveiene. Den virker umiddelbart og har en virketid på 20-30 minutter.

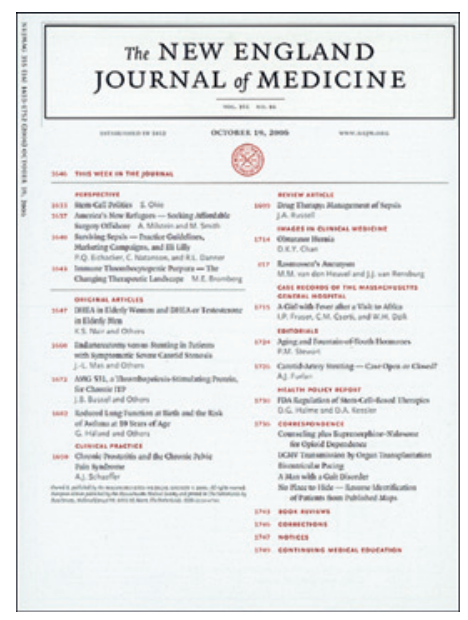

Artikkelen ble publisert 13.6. 2013 i New England Journal of Medicine (www.nejm.org), som er ett av verdens høyest rangerte medisinske tidsskrifter. (c) New England Journal of Medicine 